\title{
Endodontic management of maxillary central incisor with pulp canal obliteration
}

\author{
Abishek Lakinepally, ${ }_{1}^{1}$ Anish Poonia, ${ }^{2}$ Dileep Kishore Samarthy, ${ }^{3}$ Keerthi Edulapallii
}

${ }^{1}$ Conservative Dentistry and Endodontics, Army Dental Corps, New Delhi, India

${ }^{2}$ Pedodontics and preventive dentistry, Army Dental Corps, New Delhi, India

${ }^{3}$ Conservative Dentistry and Endodontics, SVS Institute of Dental Sciences, Mahabubnagar, Telangana, India

${ }^{4}$ Prosthodontics and crown and bridge, SVS Institute of Dental Sciences, Mahabubnagar, Telangana, India

\section{Correspondence to} Dr Abishek Lakinepally, drabi2k9746@gmail.com

Accepted 1 October 2018

\section{DESCRIPTION}

Traumatised teeth usually develop pulp canal obliterations and are characterised by radiographic loss of pulp space and yellowish discoloration of clinical crown. ${ }^{12}$ The American Association of Endodontists included teeth with radiographic indiscernible root canals requiring treatment in high difficulty criteria. ${ }^{3}$ Proper debridement, disinfection and obturation of root canal is difficult in such cases thus compromising root canal treatment. This article presents case of pulp canal obliteration of maxillary central incisor that was managed with usage of cone beam CT (CBCT), microscopes, periodic radiographs and small sized hand files which helped in achieving patency to the pulp chamber and root canal.

A 35 year old male patient reported with pain in upper front region of jaw since 3 months. The patient gave history of trauma 3 years ago when he met with an accident, thereafter he noticed gradual change
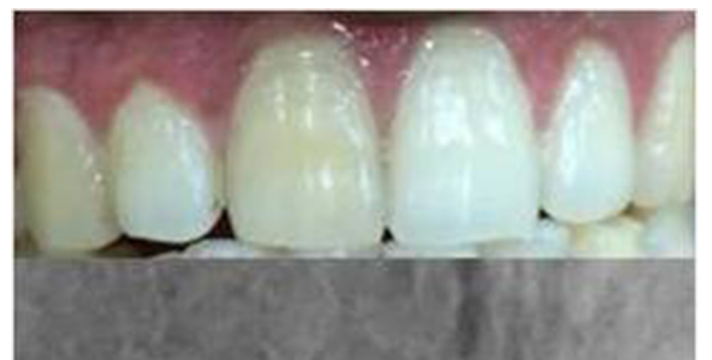

Check for updates

(c) BMJ Publishing Group Limited 2018. No commercial re-use. See rights and permissions. Published by BMJ.

To cite: Lakinepally $\mathrm{A}$, Poonia A, Samarthy DK, et al. BMJ Case Rep Published Online First: [please include Day Month Year]. doi:10.1136/bcr-2018-

227318

Figure 1 Preoperative photograph and radiograph

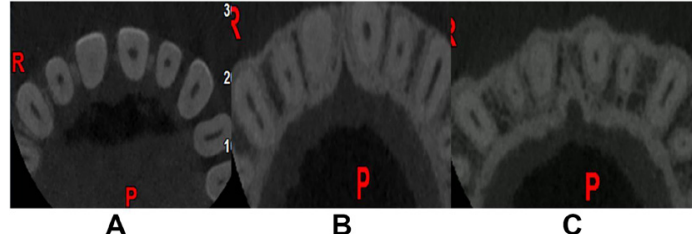

Figure 2 Cone beam CT (CBCT) axial images. (A) Coronal third section showing partially obliterated pulp chamber. (B) Middle third section showing partially obliterated pulp canal. (C) Apical third section showing partially obliterated pulp canal.

in the transparency of the crown but there was no pain. The patient elicited history of trauma again on the same tooth 3 months back when he was playing games after which he developed pain on biting. Pissiotis et $\mathrm{al}^{4}$ showed that repeated traumatic episodes have an effect on pulpal healing which increases the risk of developing pulp canal obliteration and pulp necrosis. Intraoral examination revealed discoloration of tooth 11 with tenderness to vertical percussion. Thermal and electric pulp response was negative with tooth 11 whereas adjacent teeth showed normal response. Preoperative radiograph revealed partial pulp canal obliteration with periodontal ligament widening in the apical region (figure 1). CBCT (Carestream, Rochester, NY) was taken to check the continuity and patency of canal in different levels of root. Axial section of coronal, middle and apical third of

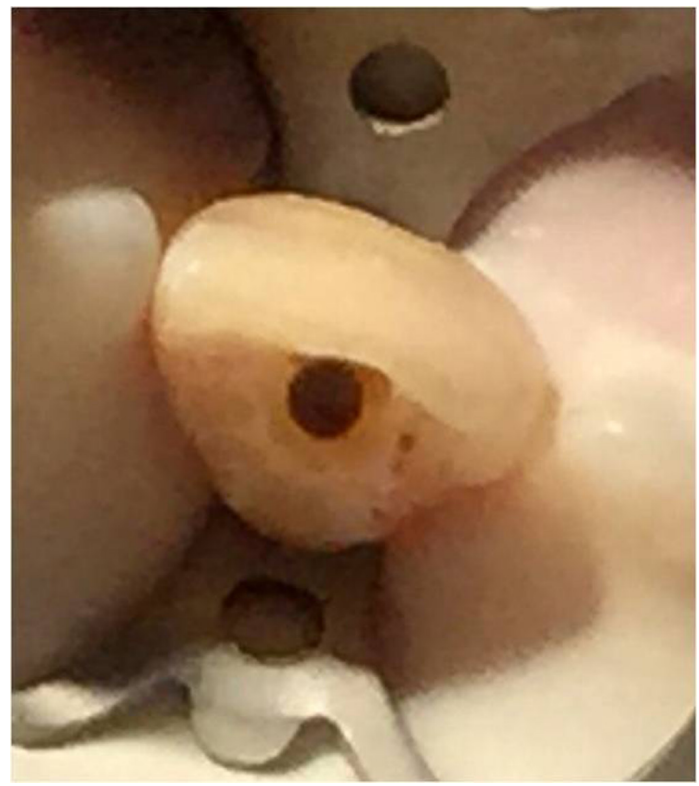
showing crown discoloration and pulp canal obliteration.
Figure 3 Access cavity preparation showing incisal preparation and straight line access. 


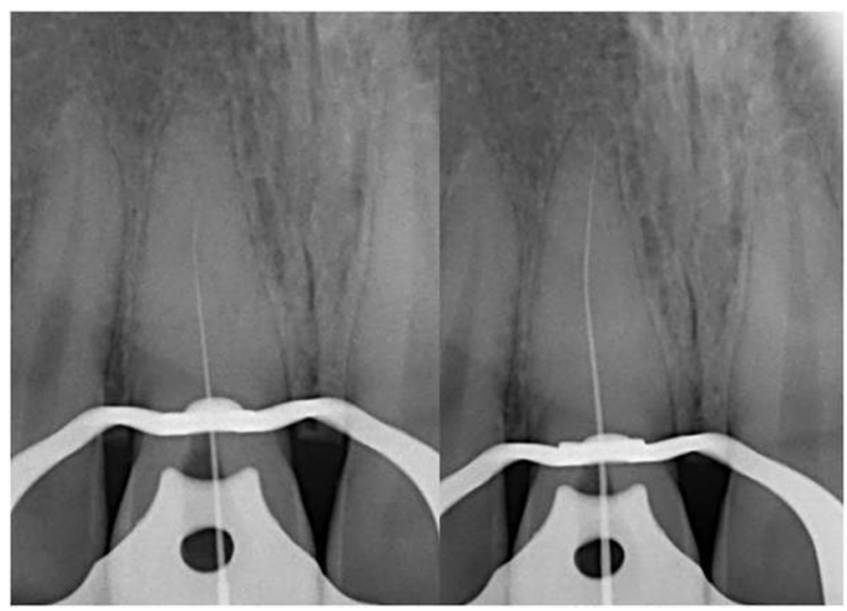

Figure 4 Periodic radiographs showing working length determination.

root revealed partially obliterated pulp chamber and pulp canal (figure 2). Diagnosis of symptomatic apical periodontitis with partial obliteration of the pulp canal was made and non surgical root canal treatment was advised to the patient. History of trauma 3 months ago may be the reason for symptomatic apical periodontitis which represents inflammation of apical periodontium producing a painful response to biting or percussion. This may or may not be associated with radiographic changes. ${ }^{5}$ After

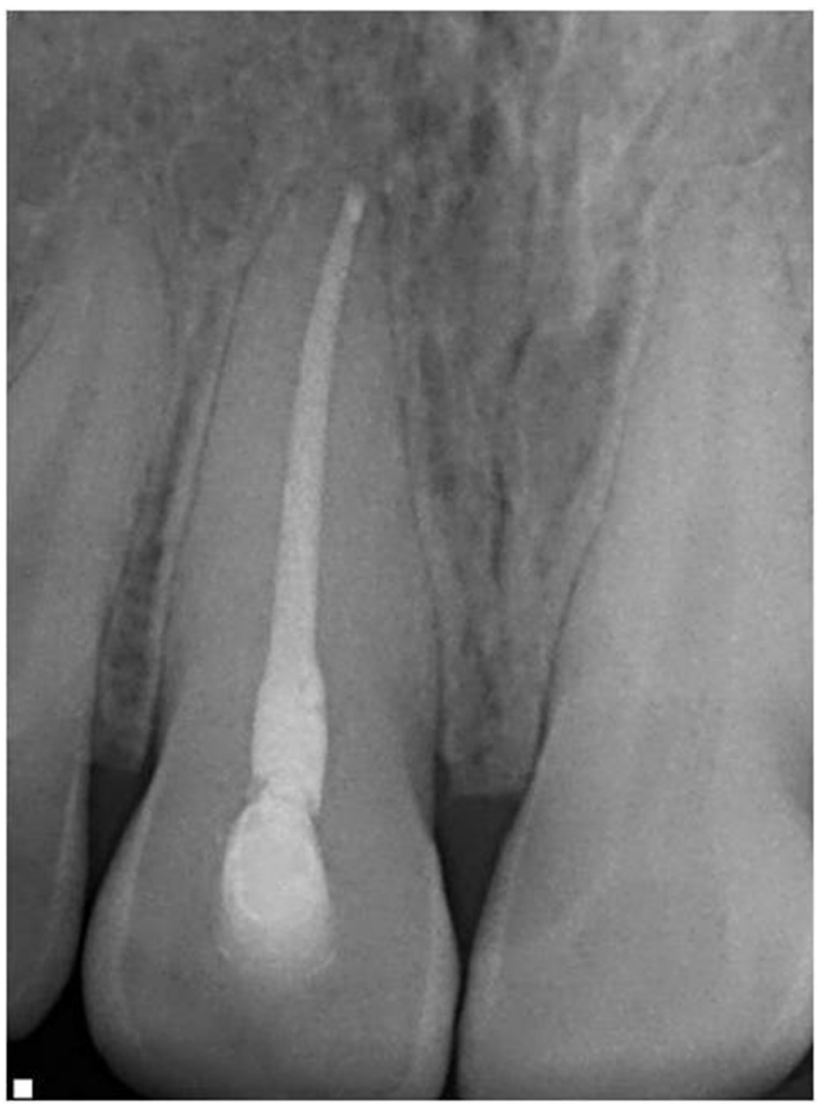

Figure 5 Three-month postoperative radiograph. obtaining consent, the tooth was anaesthetised and isolated under rubber dam. Access cavity was prepared close to incisal edge using extended shank round burs (Brasseler, Savannah, GA, USA) and ultrasonic BUC 1 tips (SybronEndo, Orange, California, USA) which facilitated straight line access. ${ }^{6}$ Scouting of the root canal orifices was done using a DG 16 explorer and visualised under surgical operating microscope (Carl Zeiss Surgical, Oberkochen, Germany) (figure 3). Size $8 \mathrm{~K}$ file (Mani, Japan) was introduced into the root canal with which obliteration was felt in the middle third. C+ files (Dentsply, Tulsa, OK, USA) have stronger buckling resistance compared with $\mathrm{K}$ files and provide easy negotiation and access to apical third of root. Size $8 \mathrm{C}+$ file was used in watch winding motion with minimal vertical pressure and regularly replaced before signs of fatigue occurred along with copious irrigation of $17 \%$ EDTA to reach till the apex. Working length was measured using an electronic apex locator (Root ZX II, J Morita, Tustin, CA) and confirmed radiographically (figure 4). The root canal was prepared by crown down approach ${ }^{7}$ using ProTaper Next rotary files to size X2 (Dentsply Maillefer, USA) with copious amount of $5.25 \%$ sodium hypochlorite (Cmident India, Delhi) as irrigant during instrumentation. Master cone radiograph confirmed the apical extent of gutta percha and obturation was completed using ProTaper Next X2 gutta-percha (Dentsply Maillefer) and $\mathrm{AH}$ Plus (Dentsply Maillefer) as endodontic sealer. The follow up was made after 3 months where the patient was asymptomatic without any tenderness (figure 5).

\section{Learning points}

- Radiographic obliteration of pulp space does not imply an absence of pulp tissue or space clinically.

- Clinical symptoms or definite radiographic findings suggestive of periapical disease are indications of root canal treatment.

- Diagnostic aids like cone beam CT, operating microscopes and proper armamentarium are the requisites to overcome the difficulties posed by pulp canal obliterations.

Contributors AL and AP have done the case. DKS and KE prepared the manuscript.

Funding The authors have not declared a specific grant for this research from any funding agency in the public, commercial or not-for-profit sectors.

Competing interests None declared.

Patient consent Obtained.

Provenance and peer review Not commissioned; externally peer reviewed.

\section{REFERENCES}

1 Oginni AO, Adekoya-Sofowora CA. Pulpal sequelae after trauma to anterior teeth among adult Nigerian dental patients. BMC Oral Health 2007;7:11-15.

2 McCabe PS, Dummer PM. Pulp canal obliteration: an endodontic diagnosis and treatment challenge. Int Endod J 2012;45:177-97.

3 American Association of Endodontics. Case Difficulty Assessment Form and Guidelines B. Chicago: American Association of Endodontists, 2006.

4 Pissiotis A, Vanderas AP, Papagiannoulis L. Longitudinal study on types of injury, complications and treatment in permanent traumatized teeth with single and multiple dental trauma episodes. Dent Traumatol 2007;23:222-5.

5 Berman LH, Diagnosis HGR. In: Cohen S, Hargreaves KM, eds. Pathways of the Pulp. 11th edn. St. Louis, MO: Mosby/Elsevier, 2011:2-39.

6 McCabe PS. Avoiding perforations in endodontics. J Ir Dent Assoc 2006;52:139-48.

7 Amir FA, Gutmann JL, Witherspoon DE. Calcific metamorphosis: a challenge in endodontic diagnosis and treatment. Quintessence Int 2001;32:447-55. 
Copyright 2018 BMJ Publishing Group. All rights reserved. For permission to reuse any of this content visit http://group.bmj.com/group/rights-licensing/permissions.

BMJ Case Report Fellows may re-use this article for personal use and teaching without any further permission.

Become a Fellow of BMJ Case Reports today and you can:

- Submit as many cases as you like

- Enjoy fast sympathetic peer review and rapid publication of accepted articles

Access all the published articles

Re-use any of the published material for personal use and teaching without further permission

For information on Institutional Fellowships contact consortiasales@bmjgroup.com

Visit casereports.bmj.com for more articles like this and to become a Fellow 